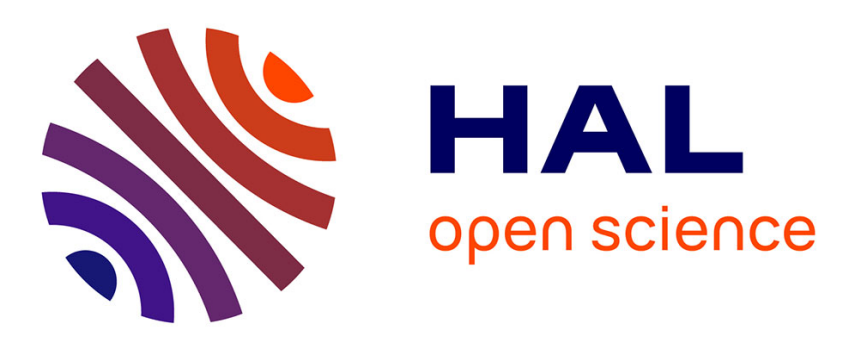

\title{
Product and Process Innovations in Subcontracting: Empirical Evidence from the French "Sillon Alpin"
}

Rachel Bocquet

\section{To cite this version:}

Rachel Bocquet. Product and Process Innovations in Subcontracting: Empirical Evidence from the French "Sillon Alpin". Industry and Innovation, 2011, 18 (7), pp.649-668. 10.1080/13662716.2011.604471 . hal-00937439

\section{HAL Id: hal-00937439 \\ https://hal.science/hal-00937439}

Submitted on 13 Feb 2014

HAL is a multi-disciplinary open access archive for the deposit and dissemination of scientific research documents, whether they are published or not. The documents may come from teaching and research institutions in France or abroad, or from public or private research centers.
L'archive ouverte pluridisciplinaire HAL, est destinée au dépôt et à la diffusion de documents scientifiques de niveau recherche, publiés ou non, émanant des établissements d'enseignement et de recherche français ou étrangers, des laboratoires publics ou privés. 


\title{
Product and process innovations in subcontracting: Empirical evidence from the French 'Sillon Alpin'
}

\author{
Rachel BOCQUET ${ }^{1}$ \\ Innovation and networks group, IREGE, University of Savoie, France
}

\begin{abstract}
This paper investigates the role that subcontracting relationships (collaborative outsourcing versus traditional subcontracting) can have on a subcontractor's ability to innovate in process and product. In order to measure the "full" impact of subcontracting relationships on innovation, we take into account the possible interaction between process and product innovations. The empirical test is based on 93 small firms operating in "pure subcontracting industries". Using a bivariate probit model, we give evidence that process and product innovations are not independent choices. The test confirms the positive impact of collaborative outsourcing agreement on the subcontractor's probability to innovate whatever the type of innovation. Finally, the results show that process and product innovations are reinforced by different inter-organizational practices and tools as well as distinct absorptive capabilities. This suggests important implications for subcontractors' competitive position.
\end{abstract}

KEY WORDS: Subcontracting relationships, small firms, product/process innovations.

JEL: L24, L26, 031, L61

${ }^{1}$ Correspondence address: Rachel BOCQUET, Innovation and Networks group, IREGE, University of Savoie, 9 Rue de l'Arc-en-ciel, BP 240, 74942 Annecy-Le-Vieux Cedex, France. Tel: +33450092346; Fax: +33450092337. E-mail: rachel.bocquet@univ-savoie.fr 


\title{
Product and process innovations in subcontracting: empirical evidence from the French 'Sillon Alpin'
}

\begin{abstract}
This paper investigates the role that subcontracting relationships (collaborative outsourcing versus traditional subcontracting) can have on a subcontractor's ability to innovate in process and product. In order to measure the "full" impact of subcontracting relationships on innovation, we take into account the possible interaction between process and product innovations. The empirical test is based on 93 small firms operating in "pure subcontracting industries". Using a bivariate probit model, we give evidence that process and product innovations are not independent choices. The test confirms the positive impact of collaborative outsourcing agreement on the subcontractor's probability to innovate whatever the type of innovation. Finally, the results show that process and product innovations are reinforced by different inter-organizational practices and tools as well as distinct absorptive capabilities. This suggests important implications for subcontractors' competitive position.
\end{abstract}

KEY WORDS: Subcontracting relationships, small firms, product and process innovations.

JEL: L24, L26, 031, L61 


\section{Introduction}

The new context of knowledge-based economy has important implications for companies operating in "pure subcontracting industries"2 (Hätönen and Eriksson 2009). Nowadays, subcontractors are not only required to simply produce but are often urged to generate the technological knowledge which fuels new product and process development. Since the early 90s, a growing body of research has endeavored to describe this new "collaborative outsourcing mode" based on interdependent and long-term relationships (Cohendet and Llerena 2005; Baudry 2004, Takeishi 2002; Amesse et al. 2001; Nonaka and Takeichi 1995). Quite surprisingly, there are very few empirical studies which provide direct information on innovation and technology transfer capabilities of subcontractors associated to this new mode (Takeishi 2002). In this paper, we would like to assess to what extent "talented suppliers" (Smith and Transfield 2005) that are placed in collaborative relationships might be more innovative or at least more actively involved in innovation than traditional subcontractors.

Besides, we know very little about the type of innovation (process and/or product) although this may be a key aspect to better understand the firms' competitive position (Weiss, 2003). The special attention given to the possible interaction between product and process innovations makes this study different from other studies that focus only on product innovation or sometimes on process innovation.

To assess the full impact of the type of subcontracting relationships on the ability of a subcontractor to innovate in process and product, we first specify two types of subcontractors according to the nature of their subcontracting agreements, their inter-organizational practices and tools, and their absorptive capacities (Cohen and Levinthal 1990). Secondly, we measure this impact according to the type of subcontractors' innovation (process and/or product). By following the Oslo Manual (OECD 2005), we define innovation in a comprehensive way at

\footnotetext{
${ }^{2}$ Pure subcontracting industries are considered those in which $80 \%$ of the turnover derives from subcontracting activity (Sessi 2007). These industries are not delineated according to a sectoral base (nature of the final output) but to a destination base (volume of the collected activity).
} 
the decision making level of the firm. There will be innovation when the firm has introduced a substantially improved or completely new product and/or process in the last three years (2004-2006).

The empirical analysis is based on data collected from subcontracting firms in May 2007. All firms were operating in "pure subcontracting industries". They are by nature quasi-firms insofar as they depend more or less on other firms. Pure subcontracting industries are also made up of a large number of small independent companies which operate in traditional or low-tech activities (Sessi 2007). The study was conducted in one of the biggest industrial subcontracting regions in France: the "Sillon Alpin".

By estimating a bivariate probit model we have made several advances. Firstly, in line with previous empirical studies, results show that process and product innovations are not independent. Secondly, the test confirms the positive impact of a collaborative outsourcing agreement on the subcontractor's probability to innovate whatever the type of innovation. Finally, we give evidence that product and process innovations are associated with differentiated inter-organizational practices and tools and distinctive absorptive capabilities.

The paper is organized as follows: Section 2 presents the theoretical foundations of the research; Section 3 sets out the empirical procedure and describes the dataset; Section 4 discusses the empirical results. In Section 5 we conclude with several theoretical implications and primary conclusions for policy makers.

\section{Innovation in subcontracting firms}

Studying subcontracting is difficult since it has been defined, elaborated and used differently. Technology transfer literature considers subcontracting as an asymmetric inter-firm relationship. Marketing and purchasing literature focuses on subcontracting as partnering in the context of single development projects. The concept itself remains multi-faceted and 
heterogeneous (Amesse et al. 2000): it is linked with opportunism and capabilities dimensions (MacIvor 2009) and distinct levels of analysis (the interfirm relationship as a whole versus the single development project). Moreover, the primary concern of most studies is to analyze subcontracting from the point of view of contractors, neglecting the suppliers' innovation performance (Nobeoka et al., 2002). In order to have a more integral framework, we consider transaction-based and knowledge-based approaches of the firm. This allows us to distinguish traditional subcontracting from collaborative outsourcing and understand their potential impact on subcontractors' innovation (2.1). Then, we clarify the "true" impact of subcontracting relationships by differentiating product and process innovations, taking into consideration their possible interaction (2.2).

\subsection{Subcontracting relationships and innovation}

In transaction cost theory (Williamson 1985 1999), subcontracting is merely a practice driven by cost reduction. This does not mean that there is no room for knowledge creation or innovation but these processes are a by-product of the division of labor (Williamson 1999). According to Baudry (2003), two types of "traditional" subcontractors can be identified: subcontractors of economy and subcontractors of specialization ${ }^{3}$, which differ mainly by their degree of dependence and the uncertainty level of their relationship. However, both share the same objective of producing goods and services under the guidance of large firms according to detailed knowledge specifications. Traditional subcontractors produce peripheral products that do not involve specific assets. This makes it more cost effective for a contractor to outsource if market incentives can be maintained and bureaucratic distortion avoided. The challenge for the contractor is to avoid a situation of capacity dependence. Subcontracting

\footnotetext{
${ }^{3}$ Used to making a product itself, a firm exceptionally delegates this particular production to a subcontractor of economy because of temporary overloading or technical failure. In contrast, whenever a firm, because of its own strategy, does not intend to master a specific part of the industrial process, it will then call for a specialized subcontractor. The latter is selected using double criteria of know-how and technical equipment (Sessi, 2007).
} 
relationships are therefore based on arm's length contracts which are uncertain by nature and dependent on the subcontractor's performance. Furthermore, the degree of interdependence is generally low because the activities in question are peripheral. In this way, transaction cost theory is useful to describe non innovative or less innovative subcontracting firms : "in terms of technology transfer, what is at stake in this zone (of quasi-market relations) is the exchange of artefacts, rather than innovative ideas or new tacit knowledge" (Cohendet and Llerena 2005, pp. 182-183). In most cases, subcontractors are rarely in charge of product design, which is too specific or risky to be subcontracted. Thus, if we consider the nature of this interfirm relationship, subcontractors have no incentive to innovate in process or product. Nevertheless, subcontractors might be able to improve their processes because of passive learning effects.

In contrast, the knowledge-based approach views subcontractors as "talented suppliers" (Smith and Transfield 2005) endowed with a new role in knowledge creation. Subcontracting relations are derived from the needs of contractors to access the complementary knowledge required to make their own skills valuable. Subcontractors contribute to building the knowledge base of their client and benefit from their accumulated absorptive capabilities (Nobeoka et al. 2002). Since the learning process is intrinsically social and collective (Nelson and Winter 1982), it occurs not only through imitation, but also because of joint contributions to the understanding of complex problems based on relational long term-contracts and coordinative routines. Compared to arm's length market contracts, such arrangements are more structured, involve constant interaction between firms, more open information channels, greater trust and put less emphasis on price (Teece 1996). Similarly, Van Echtelt et al. (2008) demonstrate that suppliers' involvement in product development is more effective when close relationships are adopted. Long term benefits will depend on the ability of the contractor to 
manage a process along which learning routines are built to ensure that the capacity sets of both parties are aligned and remain useful for future projects. Since the relationship can be close but adversarial, Nobeoka et al. (2002) find that it is important to distinguish between the scope and the degree of inter-firm cooperation, rather than simply assume that "the fewer the customers the more cooperative the inter-firm relationship" (p.730). They show that suppliers that cultivate highly cooperative relationships with multiple customers can benefit from more learning opportunities than suppliers with fewer customers. Here, two main arguments should be retained.

The first concerns the type of contractual agreement, which in the case of collaborative outsourcing is not a matter of dependence but of co-specialization (Teece 1996). Contractual mechanisms have to guarantee incentives for innovation. The length of the contract (mid/long term) and its explicit nature becomes a guarantee if compared to a short-term open, repetitive order, which characterizes traditional subcontracting. Then, subcontractors will be encouraged to innovate in order to reap future gains and benefit from the renewal of the contract to enjoy the fruits of the quasi-rent. The second argument relates to the weakness of the contractual dimension to qualify the full potential of subcontracting relationships. The knowledge-based approach to subcontracting is comparable to a process that depends both on the type of agreement and the quality of interaction between the contractor and subcontractor. To transfer and share knowledge, it is necessary to build routines as well as incentive schemes and information-sharing rules (Blumenberg et al. 2009). From this perspective, characterization must include inter-organizational practices and tools and absorptive capabilities of firms.

To guarantee the integration of activities and flow of knowledge between subcontractors and contractors, two types of practices and tools can be considered as determinants of the innovation learning process. The first are practices dedicated to the coordination of quality, such as insurance-quality procedures, just-in-time or lean supply (Baudry 2003). Since the 
outcome of the exchange is difficult to predict, these practices are necessary to make sure that a product or process will meet quality requirements. They also facilitate the renewal of contracts and promote the subcontractor's technological potential. Baudry (1995) shows that the closest subcontractors use coordination mechanisms that "are no longer reduced to price mechanisms but require practices and tools that reveal the ability of a subcontractor to deliver goods in due quality and time and to innovate" (p. 106). Studying the case of the lean supply model, Lamming (1993) suggests that these new practices and tools foster the ability of the subcontractor to innovate. Secondly, logistical integration tools, such as Electronic Data Interchange (EDI) or Enterprise Resource Planning software (ERP) have become strategic in the development of new forms of subcontracting that include the sharing and diffusion of knowledge (Raymond and Blili 1997). EDI help share data and applications (such as ERP) among users in different organizations (Iacovou Charalambos et al. 1995). EDI is often conducted over propriety value-added networks and controlled by one large firm ${ }^{4}$ (Zhu 2002). Studying ICT adoption modes of French industrial firms, Bocquet and Brossard (2007) show distinct behavior which leads some firms to select network-oriented ICT equipment (EDI) or software-oriented ICT equipment (ERP) while others prefer to adopt both types of ICT (EDI and ERP). The presence of an EDI can be interpreted as the signal of a network organization in which a "hub" firm decentralizes activities to subcontracting firms (Raymond and Blili 1997). Andersen (1999) has shown that EDI use depends on the subcontracting type. On the basis of 445 subcontractors in the Danish industry, he gives evidence that developmentoriented subcontractors (in both product and process) are more likely to use EDI than other traditional subcontractors.

\footnotetext{
${ }^{4}$ New tools such as Webedifacts may change the Propriety issue since the initial cost load is much less than it used to be in the EDI-days. However, Bocquet and Brossard (2008) show that industrial firms in the Sillon Alpin are late adopters in matters concerning EDI: with an adoption rate far lower than the national average, these subcontractors should not be concerned by this new kind of tool.
} 
The knowledge-based literature considers the subcontractors' absorptive capacity as a key factor for successful partnership. The absorptive capacity of firms, defined as their ability to absorb outside knowledge, reflects the cumulative nature of knowledge which is largely a function of prior related knowledge (Cohen and Levinthal 1990). In the case of collaborative outsourcing, a supplier's absorptive capacity is seen as a pre-requisite to building the contractors' knowledge base. But, "it is also important for the firm to enhance absorptive capacities of the suppliers themselves" (Cohendet and Llerena 2005, p.182). This means that a contractor does not only assist in the area of cost reduction but also in increasing technological competence. The use of external links to extend a firm's base has thus been frequently related to successful innovation. This is particularly important for small subcontractors that have to "compensate for small internal resources by being good at interacting with the outside world" (Fagerberg 2005, p. 11). Through 43 case studies in Low and Medium Tech industries of nine EU countries Hirsch-Kreisen (2008) shows that the acquisition and the generation of innovation knowledge rarely takes place within firms but relies on external knowledge sources such as customers or machine suppliers.

Another way to estimate the absorptive capacities of subcontractors is to consider the firm's strategic positioning as a determinant of its ability to learn (Fiol and Lyles 1985). Most empirical studies on subcontracting emphasize that cost-driven objectives prevail in all types of subcontracting agreements and tend to blur all other objectives. In their qualitative study on subcontracting in the aeronautical industry in Quebec, Amesse et al. (2001) show that subcontractors perceive all agreements as a result of the main contractor's cost-driven strategy, although the latter is seeking technology transfer. Dyer and Singh (1988) conclude that partnering does not differ significantly from arm's length contracts when cost-driven objectives are prevailing. In her study of 18 Finnish subcontractors, Lehtinen (1999) provides new evidence. Although she observes an increase of stable commitment-based relationships, 
partnerships involving integrated $R \& D$ processes or mutual sharing strategic visions are still very few. Smith and Tranfield (2005), studying the UK aerospace industry, find that new subcontracting practices based on lean supply give subcontractors the opportunity to have a new status and role. But, their ability for innovation is less apparent: only two subcontractors out of ten are engaged in innovation.

To sum up, the few studies that deal with knowledge creation and innovation through subcontracting relationships tend to confirm that a new type of subcontractor does exist. Theoretically, these "suppliers" differ from traditional subcontractors because of the structure of the contractual agreement, the nature of their absorptive capabilities and the interorganizational devices by which they are committed to the contractor. However, empirical results concerning the supplier's ability to innovate are still ambiguous. Some studies give evidence of the impact of certain practices and tools on innovation, while others are more pessimistic, concluding that the so-called "talented suppliers" are an ideal image rather than a reality.

\subsection{The ability to innovate in process and product}

The clear-cut distinction between product and process innovations has important implications for a better understanding of the determinants of innovation and for the competitive position of firms (Weiss 2003). Several empirical studies show that product and process innovations are closely interlinked in many firms but are driven by different industry and/or firm level variables (Vaona and Pianta, 2008, Rouvinen 2002) or organizational capabilities (Damampour and Gopalakrishnan 2001). Using the SIEPI-CIS2 database, Vaona and Pianta (2008) prove that product and process innovations are present together. In the case of small firms, process innovation is reinforced by strategies for production flexibility while product 
innovation is explained by patenting. After comparing small manufacturing firms in Germany and the United Kingdom, White et al. (1988) note that process innovation tends to be independent from product innovation when the motive is cost reduction. In contrast, process innovation tends to be more related to product innovation when the level or intensity of the latter is high or requires similar technical expertise.

Other empirical studies test if one type of innovation is a driver of the other type or if they complement each other. Kraft (1990) shows that product innovation has a significant impact on process innovation - but no evidence can be found for the reverse. In contrast, MartinezRos (2000) demonstrates that product and process innovations are complementary after checking for the presence of unobserved firm effects like managerial ability, experience, or other factors that remain constant during one period. Athey and Schmutzler (1995) show that returns on implementing a product innovation are higher when the firm also implements a process innovation in the short term.

Despite the fact that these empirical studies use different methodologies, they show that product and process innovations may not be independent choices. The possibility of an interaction between the two types of innovations cannot be rejected a priori. Besides, product and process innovations are driven by different factors. In the case of subcontracting firms, the pattern of interaction between product and process innovations is still unclear. There remains important issues: does the "true" potential of collaborative outsourcing have consequences for small manufacturers? Is the result a process or a product innovation, or both?

\section{Method}

In this section, we present the data (3.1), the empirical procedure (3.2) and the variables used in this study (3.3). 


\subsection{Data}

Data were collected in May 2007. A specially designed questionnaire was e-mailed to 1126 companies (with more than 2 employees) operating in "pure subcontracting industries" (Sessi 2007). All firms are by nature quasi-firms insofar as they are in a state of dependence (more or less favourable) regarding their contractors, particularly concerning equipment and car manufacturers who constitute the main customer sector. In the sample the share of subcontracting activity collected by firms reaches $88 \%$. The size of firms under study matches the sector-based data established on a national scale (Sessi, 2007). Over half the subcontractors are small (micro) independent firms. Sampled firms are located in the "Sillon Alpin". This region is the biggest industrial subcontracting area in France, employing 25\% of the people working in the metal cutting and forming sector. $75 \%$ of the country's mechanical and bar turning industries are concentrated in this region. In the sample, the biggest majority of subcontractors $(80,6 \%)$ belongs to the metal cutting and forming sector. This sector represents the first group of subcontracting activities nationally (Sessi 2007). If firms are operating in different activities (Bar Turning, Mechanical, Forge, Stamping, Cutting) and supply various industries such as the car industry, they compete in environments that are similar in terms of market structure and innovation. Staying dependent from their contractor and due to their small size, many firms (especially those with proprietary know-how) should be reluctant to participate in inter-firm knowledge-sharing activity.

Senior managers were asked to provide information about what type of subcontracting agreements they had, paying particular attention to the agreement with the most important contractor. We obtained details about their degree of dependence, their role in the subcontracting relationship and the level of uncertainty they face. Another part of the questionnaire was about their ability to innovate in product and process, their organizational competencies, their strategic priorities and the different sources of technical knowledge they 
use to support innovative activities. We collected 93 exploitable questionnaires ${ }^{5}$, and the final data is representative of subcontracting firms situated in the "Sillon Alpin" for the 3 sectors and the 2 size classes (See Tables A1 and A2 in Appendix).

\subsection{Empirical procedure}

Subcontracting firms innovate because it is profitable for them to do so (expected returns exceed associated costs). Expected profits of an innovator $i$ must be higher with innovation $\left(\Pi_{i}^{\mathrm{I}}\right)$ than without innovation $\left(\Pi^{\mathrm{N}} \mathrm{i}\right)$, ie:

$\mathrm{y}^{*}=\left(\Pi_{i}^{\mathrm{I}}\right)-\left(\Pi_{\mathrm{i}}^{\mathrm{N}}\right)>0$

A latent regression can be specified as:

$y^{*}{ }_{i=\alpha+}{ }^{\prime}{ }_{C} X_{C}+\beta{ }^{\prime} X_{O}+\beta{ }^{\prime} X_{S}+\beta{ }^{\prime}{ }_{S O} X_{S O}+\beta{ }^{\prime}{ }_{C O} X_{C O}+\varepsilon$

Where: $\mathrm{X}_{\mathrm{C}}$ represents the types of subcontracting agreements, $\mathrm{X}_{\mathrm{O}}$ captures the organizational practices and tools stated in the subcontracting firm, $\mathrm{X}_{\mathrm{S}}$ captures its strategic orientation, $\mathrm{X}_{\mathrm{SO}}$ characterizes the sources of knowledge used to support innovative activities, $\mathrm{X}_{\mathrm{CO}}$ represents the control variables and $\varepsilon$ is the error term (assumed to be normally distributed).

Unfortunately, the subcontractors' profits with and without innovation cannot be observed. We only observe whether it innovates or not. The observed counterpart to $y_{i}{ }_{i}$ is $y_{i}$, which takes a value of 0 (no innovation) or 1 (innovation), noted as follows:

$\mathrm{y}_{\mathrm{i}}=\left\{\begin{array}{l}1 \text { if and only if } y_{i}^{*}>0 \\ 0 \text { otherwise }\end{array}\right.$

Table 1 indicates that 16 subcontractors (17\%) qualify for the title of highly innovating firms as they have made innovations in both products and processes in the three years prior to the survey. However, estimating the probability to innovate using a probit model is restrictive

\footnotetext{
${ }^{5}$ The sampling rate is somewhat small (8\%). It can be explained by the strategic nature of the information collected and the secrecy policy which is dominant in subcontracting activities.
} 
as this supposes that the two processes are independent. As shown before, this hypothesis is not adapted because product and process innovations can be linked. It is therefore more appropriate to estimate a system of equations rather than separate estimations for each type of innovation.

Table 1. Product and process innovations of subcontractors

\begin{tabular}{lll}
\hline & \multicolumn{2}{l}{ INOPROC } \\
\hline INOPROD & 0 & 1 \\
\hline 0 & 26 & 29 \\
1 & 22 & 16 \\
\hline
\end{tabular}

For the two types of innovation, process and product, respectively noted $j$ and $k$, we have:

$\left\{\begin{array}{l}\mathrm{P}\left(\mathrm{y}_{\mathrm{ij}}=1\right)=\Phi\left(\beta^{\prime}{ }_{\mathrm{j}} \mathrm{X}_{\mathrm{ij}}+\varepsilon_{\mathrm{ij}}\right) \\ \mathrm{P}\left(\mathrm{y}_{\mathrm{ik}}=1\right)=\Phi\left({ }^{\prime}{ }_{\mathrm{k}} \mathrm{X}_{\mathrm{ik}}+\varepsilon_{\mathrm{ik}}\right)\end{array}\right.$

Where $\beta$ is a vector of coefficient, $X_{i}$ denotes the vector of explanatory variables, and $\varepsilon_{i j}$ and $\varepsilon_{i k}$ the error terms which follow a bivariate normal distribution with zero mean, unit variances and $\rho$ is the correlation coefficient of the error terms. We used a bivariate analysis to test the correlation between the types of innovation. The test was carried out with a simple t test on the $\rho$ coefficient. If $\rho$ is statistically different from zero, the two innovation processes are not independent and should not be estimated separately.

Before presenting the econometric results, we first describe the variables used in the regressions (see Table 4).

\subsection{Measures}

\subsubsection{Dependent variables}

By following the Oslow Manual and the Community Innovation Survey, we privilege the "subject" approach of innovation (Mairesse and Mohnen 2010). The information is collected at the firm-level, including all its innovation outputs and activities. This implies that we do not have data on particular innovation projects. Innovation can be classified by basic purpose (products and processes) and degree of novelty (new to the firm and/or new to the industry). 
In this study, we do not differentiate between subcontractors by the intensity of innovation since this is mainly incremental in traditional and low-tech industries (De jong and Marsili 2006). Process innovation (INOPROC) and product innovation (INOPROD) are examined as two binary measures of whether or not new or significantly modified production processes or products were introduced in the 3 years prior to the survey ${ }^{6}$.

\subsubsection{Independent variables}

The covariates used in the regression correspond to the four following series of variables.

Types of subcontracting agreements. The type of contractual agreement is recorded from three dimensions derived from studying the literature (see section 2): the role played by the subcontractor in the relationship, the scope and the degree of dependence on its main contractor and the level of uncertainty. The operationalization of these dimensions has been accomplished with seven core variables used before (see Table 2 hereafter).

Table 2. Definition of the variables used in the cluster analysis

\begin{tabular}{|c|c|}
\hline Variables & Definition \\
\hline REAL & $=1$ if the subcontractor manufactures products only ( $=0$ otherwise $)$ \\
\hline CONCEPT & $\begin{array}{l}=1 \text { if the subcontractor participates (even partially) in the development of the products / } \\
\text { processes ( } 0 \text { otherwise) }\end{array}$ \\
\hline NDO & $=$ Total number of contractors \\
\hline VOLP & $\begin{array}{l}=\text { Part of the collected subcontracting activity from the main contractor / total volume of } \\
\text { production of the subcontractor }\end{array}$ \\
\hline CONTRACT & $=1$ if the contract is written $(=0$ otherwise $)$ \\
\hline DUREE1 & $=1$ if the duration of the agreement is less or equal to 1 year ( $=0$ otherwise) \\
\hline RENEG & $=1$ if the agreement is systematically submitted to renegotiation ( $=0$ otherwise $)$ \\
\hline
\end{tabular}

A principal component analysis ${ }^{7}$ (PCA) was conducted on these seven variables. The MSA test (Hair et al. 1998) showed that all the variables were good candidates for a PCA (MSA values $>0.5$ ). In addition, KMO and Bartlett's test of sphericity met common standards

\footnotetext{
${ }^{6}$ In this study, we adopt an absolute definition of innovation since we consider that all firms are innovative as soon as they declare to be innovative. As noted by Freel (2000), the use of a minimum threshold for the share of sales attributed to new or modified products/processes would allow us to check the robustness of our results. Unfortunately, like many authors that examine the choice between product and/or process innovations (Vaona and Pianta 2008; Rouvinen 2002; Martinez-Ros 2000), we do not have such information.

${ }^{7}$ All these results are available from the author on request.
} 
$(\mathrm{KMO}=0.55$ and $\mathrm{p}<0.001)$. The PCA uncovered three factors that summarize the theoretical dimensions well (59.8\% of the total explained variance). A non-hierarchical cluster analysis was then carried out on the factor scores. To determine the final number of clusters, we used three usual criteria: (i) the statistical accuracy of the classification measured by the ratio of within and between cluster variances, (ii) the number of firms per cluster, and (iii) the economic significance of the clusters identified. According to the criteria, the version with two clusters of subcontracting firms was preferred ${ }^{8}$. The variable DUREE1 could not be used to describe the profile of clusters as there was no significant effect. This suggests that subcontractors (whatever their profile) are placed in similar conditions concerning the duration of their agreement. The two clusters can be interpreted as follows (see Table 3):

In Cluster 1, 41 subcontractors (44.1\%) manufacture products only and do not have a free hand in product or process development. They are very dependent on their contractors (due to the small number of contractors, and the authority of the main one). The presence of arm's length contracts, which are continually in the balance, conforms to traditional subcontracting.

In Cluster 2, 52 subcontractors $(55.9 \%)$ participate in product/process conception. Subcontractors are linked to a larger number of contractors and the weight of the main contractor is weaker than in Cluster 1 , although it is still $22 \%$ of the total volume of production. Contracts are established (written) and are less risky than with traditional subcontractors (not systematically renegotiated), which reflects relationships based on trust and reciprocity. This type of agreement corresponds more to collaborative outsourcing based on incentive schemes as well as routines for the coordination of knowledge and learning process.

The two dummy variables $(\mathrm{C} 1$ for traditional subcontracting and $\mathrm{C} 2$ for collaborative outsourcing) used in the econometric analysis, result from this classification procedure.

\footnotetext{
${ }^{8}$ For all comparisons of variances, Fisher's test is significant at the 0.000 level and indicates a good differentiation of the subcontracting firms.
} 
Table 3. Interpretation of the two subcontracting clusters

\begin{tabular}{|c|c|c|c|c|c|c|c|}
\hline & & NDO & VOLP & CONTRAT & CONCEPT & REAL & RENEG \\
\hline \multirow{2}{*}{$\begin{array}{l}\text { C1: Traditional } \\
\text { subcontracting }\end{array}$} & Mean & 28.00 & 37.88 & .02 & .12 & .95 & .71 \\
\hline & $\mathrm{N}$ & 41 & 41 & 41 & 41 & 41 & 41 \\
\hline \multirow{2}{*}{$\begin{array}{l}\text { C2: Collaborative } \\
\text { outsourcing }\end{array}$} & Mean & 86.90 & 22.33 & .31 & .37 & .65 & .54 \\
\hline & $\mathrm{N}$ & 52 & 52 & 52 & 52 & 52 & 52 \\
\hline Total & Mean & 60.94 & 29.18 & .18 & .26 & .78 & .61 \\
\hline
\end{tabular}

Organizational practices and tools. To reveal how much integration exists between subcontractors and contractors we use two series of variables. The first is related to the existence of a shared information system through the use of the EDI network and/or ERP applications. The second series of variables aims to identify the presence of practices dedicated to the coordination of quality in new forms of subcontracting (Baudry 2003): FORM indicates if there are formal agreements between subcontractors and their suppliers or contractors, QUALI informs about the adoption of organizational practices centered on quality management. LPJAT reveals if subcontractors have implemented a "just-in-time" logistical organization.

Sources of knowledge. Like many authors, we underline the importance of external sources of knowledge used by subcontractors as a complement to their internal sources. Four variables were used to distinguish external sources from internal ones. The external sources are defined as follows: PREST stands for firms that collaborate with external providers to acquire new knowledge (private firms specialized or not in R\&D and innovation, technical centers, public research centers, associations). ACTIFS identifies firms that buy specific assets to innovate such as patents, licenses or machines. As far as internal sources are concerned, we distinguish firms that rely on their own R\&D or engineering departments (BERD) from those that recruit new workers or train staff to support their innovative activities (RH). 
Strategy variables. To complete the specification of the absorptive capabilities of subcontractors, we have included a menu of variables related to their strategic objectives. This provides the following explanatory variables DEVINOV (development of R\&D or innovation), RATION (cost-reduction), REDUCDEP (reduction of dependence from contractors), DIVER (market diversification).

Control variables. Two control variables have also been defined: firm size is measured by EFF1 (less than 10 employees) and EFF2 (10 employees or more). As far as industrial affiliation of subcontractors is concerned, we have undertaken some regrouping inside the $\mathrm{SIC}^{9}$ four digit level, in order to acknowledge the two main activities of the metal cutting and forming sector in the "Sillon Alpin": bar turning (DEC) and mechanical (MECA). The other subcontracting activities are noted as APE2.

\footnotetext{
${ }^{9}$ Standard Industrial Classification
} 
Table 4. Definition of variables

\begin{tabular}{|c|c|}
\hline Dependent variables & Definition \\
\hline INOPROC & $\begin{array}{l}=1 \text { if the firm has introduced a substantially improved or a completely new process } \\
\text { in the last three years ( }=0 \text { otherwise })\end{array}$ \\
\hline INOPROD & $\begin{array}{l}=1 \text { if the firm has introduced a substantially improved or a completely new product } \\
\text { in the last three years ( }=0 \text { otherwise })\end{array}$ \\
\hline Independent variables & Definition \\
\hline \multicolumn{2}{|c|}{$\begin{array}{l}\text { Subcontracting agreements (Ref. } \mathrm{Cl}=1 \text { if the type of subcontracting agreement corresponds to traditional } \\
\text { subcontracting) }\end{array}$} \\
\hline $\mathrm{C} 2$ & $\begin{array}{l}=1 \text { if the type of subcontracting agreement corresponds to collaborative outsourcing } \\
(=0 \text { otherwise })\end{array}$ \\
\hline \multicolumn{2}{|c|}{ Organizational practices and tools } \\
\hline QUALI & $\begin{array}{l}=1 \text { if the firm has adopted organizational practices centered on quality management } \\
\text { such as certification, total productive maintenance, value analysis ( } 0 \text { otherwise) }\end{array}$ \\
\hline LPJAT & $=1$ if the firm has adopted a "just-in-time" logistical organization ( $=0$ otherwise $)$ \\
\hline EDI & $\begin{array}{l}=1 \text { if the firm has adopted an Electronic Data Interchange (EDI) system }(=0 \\
\text { otherwise) }\end{array}$ \\
\hline ERP & $\begin{array}{l}=1 \text { if the firm has adopted an Enterprise Resources Planning (ERP) software (= } 0 \\
\text { otherwise) }\end{array}$ \\
\hline EDI_ERP & $\begin{array}{l}=1 \text { if the firm has adopted an EDI system and an ERP planning software ( }=0 \\
\text { otherwise) }\end{array}$ \\
\hline \multicolumn{2}{|l|}{ Strategy variables } \\
\hline DEVINOV & $=1$ if the firm aims to develop R\&D or innovation ( $=0$ otherwise) \\
\hline RATION & $=1$ if the firm aims to reduce costs $(=0$ otherwise $)$ \\
\hline RATION_DEV & $\begin{array}{l}=1 \text { if the firm aims to develop R\&D or innovation and aims to reduce costs ( }=0 \\
\text { otherwise) }\end{array}$ \\
\hline REDUCDEP & $=1$ if the firm aims to reduce the dependence from its contractors ( $=0$ otherwise $)$ \\
\hline DIVER & $=1$ if the firm aims to sell in new markets ( $=0$ otherwise) \\
\hline \multicolumn{2}{|c|}{ Sources of knowledge to support innovative activities } \\
\hline BERD & $\begin{array}{l}=1 \text { if the firm resorts to its research or production engineering departments to } \\
\text { innovate ( }=0 \text { otherwise) }\end{array}$ \\
\hline PREST & $=1$ if the firm turns to external providers to innovate $(=0$ otherwise $)$ \\
\hline ACTIFS & $\begin{array}{l}=1 \text { if the firm buys specific assets to innovate (such as patents, licenses, machines) } \\
(=0 \text { otherwise) }\end{array}$ \\
\hline RH & $\begin{array}{l}=1 \text { if the firm recruits new competences or trains the staff to innovate }(=0 \\
\text { otherwise) }\end{array}$ \\
\hline \multicolumn{2}{|c|}{ Control variables } \\
\hline \multicolumn{2}{|c|}{ Firm size (ref. EFF2 $=1$ if the firm has 10 employees or more) } \\
\hline EFF1 & $=1$ if the firm has less than 10 employees $(=0$ otherwise $)$ \\
\hline \multicolumn{2}{|c|}{ Industrial sector (ref. MECA $=1$ if the firm operates in the mechanical industry) } \\
\hline DEC & $=1$ if the firm operates in the bar turning industry $(=0$ otherwise $)$ \\
\hline APE2 & $=1$ if the firm operates in other pure subcontracting industries ( $=0$ otherwise $)$ \\
\hline
\end{tabular}

\section{Results}

We estimated the system of equations defined in Eq. 4, with a bivariate probit model. As regards the robustness of the model, we used White's procedure (1982) to deal with any potential heteroscedasticity problems. The percentage of correct predictions $(60.2 \%)$ suggests 
that the model has a good explanatory power compared to the "naïve prediction ratio" of $25 \%$

Table 5. Results of the bivariate probit model.

\begin{tabular}{|c|c|c|c|c|c|c|c|c|}
\hline \multirow[b]{3}{*}{ Variables (x) } & \multicolumn{8}{|c|}{ INOPROC-INOPROD } \\
\hline & \multicolumn{2}{|c|}{ INOPROC $\left(\mathrm{y}_{\mathrm{j}}\right)$} & \multicolumn{2}{|c|}{ INOPROD $\left(\mathrm{y}_{\mathrm{k}}\right)$} & \multicolumn{4}{|c|}{ Marginal effects } \\
\hline & $\beta$ & $\sigma_{\beta}$ & $\beta$ & $\sigma_{\beta}$ & $\begin{array}{l}y_{i j}=1 \\
y_{i k}=0\end{array}$ & $\begin{array}{l}y_{\mathrm{ij}}=1 ; \\
\mathrm{y}_{\mathrm{ik}}=1\end{array}$ & $\begin{array}{l}y_{\mathrm{ik}}=1 ; \\
\mathrm{y}_{\mathrm{ij}}=0\end{array}$ & $\begin{array}{l}\mathrm{y}_{\mathrm{ik}}=0 ; \\
\mathrm{y}_{\mathrm{ij}}=0 ;\end{array}$ \\
\hline Constant & $-2.28 * * *$ & 0.95 & -0.60 & 0.78 & & & & \\
\hline $\mathrm{C} 2$ & $0.90^{* *}$ & 0.91 & $0.69 * *$ & 0.30 & 0.17 & $0.18^{* * *}$ & 0.07 & $-0.42 * * *$ \\
\hline QUALI & $0.90^{* *}$ & 0.40 & -0.40 & 0.37 & $0.29 * *$ & 0.04 & -0.20 & -0.14 \\
\hline LPJAT & 0.05 & 0.37 & 0.39 & 0.32 & -0.03 & 0.05 & 0.08 & -0.10 \\
\hline EDI & -0.29 & 0.42 & 0.03 & 0.41 & -0.08 & -0.02 & 0.03 & 0.07 \\
\hline ERP & $1.95^{* * *}$ & 0.61 & -0.71 & 0.55 & $0.50^{* * *}$ & 0.09 & $-0.33 * * *$ & $-0.26 * * *$ \\
\hline EDI ERP & $-2.56^{* * *}$ & 0.94 & $2.44 * * *$ & 0.82 & $-0.47 * * *$ & -0.04 & $0.70^{* * *}$ & $-0.18 * *$ \\
\hline RATION & -0.46 & 0.67 & -0.47 & 0.53 & -0.03 & -0.14 & -0.03 & 0.21 \\
\hline DEVINOV & $-2.31 * * *$ & 0.78 & 0.11 & 0.58 & $-0.54 * * *$ & -0.18 & 0.22 & 0.50 \\
\hline RATION_DEV & $2.67^{* * *}$ & 0.89 & -0.50 & 0.69 & $0.48^{* *}$ & 0.18 & $-0.35^{* * *}$ & $-0.31 * * *$ \\
\hline REDUCDEP & $-0.82 *$ & 0.45 & -0.45 & 0.37 & -0.20 & $-0.10 * *$ & -0.06 & $0.37 * *$ \\
\hline DIVER & -0.90 & 0.61 & -0.25 & 0.38 & -0.16 & $-0.24 * *$ & 0.15 & $0.25^{* * *}$ \\
\hline BERD & $2.66^{* * *}$ & 0.38 & 0.17 & 0.42 & $0.34 * *$ & $0.37 * * *$ & $-0.31 * * *$ & $-0.40 * * *$ \\
\hline PREST & $1.08^{* *}$ & 0.44 & 0.16 & 0.37 & 0.20 & $0.19^{* *}$ & -0.13 & $-0.26 * * *$ \\
\hline ACTIFS & 0.72 & 0.50 & 0.72 & 0.52 & -0.02 & $0.30 * *$ & -0.02 & $-0.25 * * *$ \\
\hline $\mathrm{RH}$ & 0.46 & 0.33 & $0.77 * *$ & 0.33 & 0.05 & $0.13^{* *}$ & 0.14 & $-0.32 * * *$ \\
\hline EFF1 & $1.52^{* * *}$ & 0.43 & -0.42 & 0.33 & $0.44^{* * *}$ & $0.10^{*}$ & $-0.26^{* * *}$ & $-0.28 * *$ \\
\hline DEC & $1.02 * * *$ & 0.38 & 0.26 & 0.40 & 0.20 & $0.18^{*}$ & -0.08 & $-0.30 * * *$ \\
\hline APE2 & $1.63 * * *$ & 0.39 & 0.46 & 0.39 & $0.27 * *$ & $0.31^{* * *}$ & -0.13 & $-0.44 * * *$ \\
\hline$\rho$ & \multicolumn{8}{|c|}{$-0.94 * *(0.38)$} \\
\hline $\begin{array}{l}\text { Number of } \\
\text { observations }\end{array}$ & \multicolumn{8}{|c|}{93} \\
\hline Log-likelihood & \multicolumn{8}{|c|}{-80.6} \\
\hline Wald test of $\rho$ & \multicolumn{8}{|c|}{$6.01 * *$} \\
\hline $\begin{array}{l}\text { Rate of good } \\
\text { predictions }\end{array}$ & \multicolumn{8}{|c|}{$60,2 \%$} \\
\hline
\end{tabular}

The first important result concerns the statistical link between the two innovation choices.

In Table 5, the correlation coefficient Rho is significantly different from zero suggesting that process and product innovations are not independent choices. Thus, the estimation of two separate models would lead to a loss of efficiency and possible misleading results (Rouvinen 2001).

\footnotetext{
${ }^{10}$ Four probability scores can be computed $P_{00}=$ probability of no innovation; $P_{0 I}=$ probability to innovate in product only; $P_{10}=$ probability to innovate in process; $P_{1 I}=$ probability to innovate in process and product.
} 
Clearly, product and process innovation are affected by different factors. This confirms previous empirical results that make a clear distinction between the two types of innovation: process and product innovations only have the type of subcontracting agreement in common. As expected, the type of subcontracting agreement explains the ability to innovate of a small manufacturer. Suppliers (C2) are more likely to innovate than traditional subcontractors $(\mathrm{C} 1)$. When arrangements are well-established and not systematically renegotiated, and when suppliers are invited to play an active role in design, new critical components (trust and reciprocity) are introduced that favor their ability to innovate both in product and process.

As suggested by the knowledge-based perspective, the nature of the contract is not sufficient to assess the full role of subcontracting relationships on innovation patterns. Other factors such as the presence of organizational practices and tools and the absorptive capacities of subcontractors are likely to impact on their ability to innovate. These variables have a positive impact on innovation. The likelihood to innovate is higher if subcontractors have adopted organizational practices centered on quality management (QUALI) and logistical tools (ERP and EDI_ERP). This confirms the importance of the "quality" of integration between contractor and subcontractor. However, few variables have a positive effect, meaning that innovation capabilities are not necessarily supported by all new practices. This result matches the literature on new practices in subcontracting (including lean practices) which underline their weak impact on subcontractors' innovation capabilities. Furthermore, and more interestingly, process and product innovations are not affected by the same organizational practices or IT tools.

Process innovation is helped by the presence of quality-oriented practices and ERP software while the use of both EDI and ERP (cross variable) diminishes the likelihood to innovate in process. In contrast, product innovation depends on the sole combination of both EDI and ERP technologies, and is not affected by quality oriented practices. Considering the 
complementarity between ICT, we note that sharing an information system with a hub firm has a positive effect on product innovation and an opposite effect on process innovation. This result is in line with recent developments on new forms of subcontracting. The presence of such a logistical integration, which is sometimes comparable to an irreversible organizational investment, consists of the implementation of a common language between principals and subcontractors. What is at stake here is the mutual exchange of complementary forms of knowledge between firms for the co-conception of new products. In contrast, process innovation is associated with ERP and organizational practices centered on quality management mainly aiming for cost reduction. These devices do not concern the technological potential of the subcontractor.

As for the strategic variables, the formulation of a clear objective oriented towards R\&D or innovation (DEVINOV) decreases the probability to innovate in process. Besides, process innovation is explained by a cross effect that measures the pursuit of cost-driven and innovation objectives. This result, in line with previous studies, shows that "even when the main contractor is concerned by technology transfer, cost-driven actions blur the technological objectives of any type of subcontracting agreement" (Amesse et al. 2001, p. 568). Quite surprisingly, strategic objectives oriented towards R\&D and innovation, are not positively associated with product innovation. A candidate explanation for this result is that product innovation is a never ending improvement process rather than an asserted strategy of R\&D or new product development. As noted by Pavitt (1984), “competitive success [of small specialized suppliers] depends to a considerable degree on firm-specific skills reflected in continuous improvements in product design and in product reliability" (p. 359). This explanation is strengthened if we consider the sources of knowledge which support the innovative activities of subcontractors. The role of firm-specific skills is captured by the significant and positive effects of internal R\&D and engineering activities (BERD) on process 
innovation and the recruitment of new competence and staff training on product innovation $(\mathrm{RH})$. Though different, the internal sources play a significant role on both types of innovation. The significant link between process innovation and BERD is well-explained by the fact that small subcontractors in metal manufacturing produce a relatively high proportion of their own process technology (Pavitt 1984). Process innovation is also driven by external sources of knowledge. This supports the absorption capacity hypothesis (Cohen and Levinthal 1990). In contrast, product innovators solely rely on their main contractor as a source of innovation. Following Bruce and Moger (1999), the relationship between supplier and contractor seems too close. This reduces the subcontractor's absorptive capacity and leads to a failure to absorb and benefit from external sources of innovation (Pardo and Rama 2009).

Considering the control variables, sectoral variables are never related to product innovation only. The fact that process innovation is significantly associated with APE2 (rubber and plastic products) matches well the behavior of "science-based" firms. These firms innovate both in process and product, with a prevalence of process over product.

Firms operating in metal manufacturing sectors belong to the cluster of "suppliers of intermediate goods" (Archibughi and al. 1991), or "supplier-dominated firms" (De Jong and Marsili 2006) which are mainly small process-oriented firms. As observed by these authors, micro-firms (from 1 to 9 employees) are over-represented among supplier-dominated firms.

Finally, the metal cutting and forming sector (that represent more than $80 \%$ of the sample) refers to important aspects of low-tech industries with specific innovation modes (HirschKreinsen 2008). With a high percentage of small firms, innovation is less technology oriented than those of High and Medium Tech firms. Though process innovators are innovating through external sources, the main customer still appears to be the primary source of innovation for most suppliers. Collaborations with external partners such as providers, 
scientific institutions, specialized consultants, etc. does not appear to be as systematic as it is in HMT industries.

\section{Conclusion}

Innovation is seen as a crucial factor for the survival and competitive strength of small firms. This paper shows that a small subcontractor's ability to innovate is a complex phenomenon driven by multiple influences, including the type of subcontracting agreements, the nature of inter-organizational practices and tools, and the "quality" of the subcontractor's absorptive capabilities. Contrary to the majority of studies that focus either on product or process innovation, the results indicate that the interaction between the types of innovation themselves is also complex since they are not independent choices. The clear-cut distinction between product and process innovations in subcontracting relationships leads to important conclusions.

Firstly, this study has revealed the impact of the type of subcontracting agreement on the subcontractor's ability to innovate. Being a supplier rather than a traditional subcontractor increases the likelihood of innovation in both process and product. This supports the claim that subcontracting relationships are not only a mere practice driven by cost-reduction. Today subcontracting relationships are changing as contractual agreements give more scope for mutual commitment. This result is in line with the new generation of industrial organization theory. Small contractors may move from a dependent status to the category of innovating firm by upgrading their own innovation and technology transfer capabilities with, in some instances, the help of their main contractors. This result outlines both the role and the responsibility of the contractor in relation to the future of traditional subcontractors and their survival. Bearing in mind that $44.1 \%$ of subcontractors operate in uncertain conditions and with strong dependence, it is not surprising that these subcontractors are less committed to 
innovation than suppliers since their contractual arrangements provide per se no incentive to innovate.

Secondly, we have shown that subcontractors differ according to the type of innovation. Process innovation is supported by the pursuit of two objectives: cost reduction and innovation. Furthermore, subcontractors are more likely to innovate in process when their activities have been integrated with their contractors in quality and information sharing (QUAL and ERP). But, this operational integration is circumscribed to a dyadic relationship to foster process innovation. In contrast, product innovation is influenced by EDI and ERP tools that play a crucial role in the sharing of information and diffusion of innovation in a network-organization. We also give evidence that product and process innovations are not affected by the same sources of knowledge. In the case of process innovation, subcontractors are more likely to innovate in process if they use formal R\&D and other lower sources of technical knowledge such as engineering and external providers. Product innovation is strengthened by the recruitment of new competence and staff training. The fact that external providers do not affect product innovation means that subcontractors rely heavily on the sole understanding of the contractors' need to innovate. Even though we must remain cautious, it seems that product innovation is more likely to emerge in a network-organization under the control of the prime contractor. In this case, relationships that are too close may be a substitute rather than a complementary source to the innovation process, with some risks of lock-in for the supplier. Consistent with Nobeoka et al. 2002, one main challenge for subcontractors is to lessen their dependence by enlarging their customer scope once they strengthen their own innovation capabilities.

Thirdly, the firms' characteristics and innovation modes in pure subcontracting industries are very close to those found in Low-Tech industries. Subcontractors are mostly process 
innovators showing that cost-minimization and flexibility are still major sources of competitiveness for most small subcontracting firms.

The results of this explanatory research suggest further issues for policy makers and theoretical implications. In France, the setting up of "competitiveness clusters" is an attempt to bridge the innovation gap of small firms, and new public policies are being implemented to help subcontractors to innovate. However, although these policies are useful, they often miss their goal. They are too often directed at subcontractors (without differentiating them) or certain contractors (the most involved), so neglecting the relationship itself. It is time that policy makers recognize that the ability of a subcontractor to innovate depends on the nature of the subcontracting relationship and requires an alignment of their organizational practices and tools (Van Echtelt et al. 2008). Any attempt to bring a contractor close to its subcontractors might prove a useful step to create true partnership relations based on shared representations. The study shows that the theoretical model of partnership described by the knowledge-based perspective is still a distance from its practical expression in pure subcontracting industries.

The significant and positive impact of internal sources of knowledge on innovation is another key point in this study. As pointed out by Freel and Harrison (2006), internal resources are crucial and "networking is neither a sufficient nor, even, a necessary condition for innovation" (Op. Cit, p. 301). This conclusion is strengthened in the case of collaborative outsourcing if the potential of innovation of the subcontractors is looked for. We think that policy makers should develop the internal learning and absorptive capabilities of subcontractors. Some initiatives have already been conducted in this way. For instance, to compensate for resource and capability shortages of micro-firms, diverse forms of groupings have been initiated. These allow firms to propose global solutions to customers relying on their complementarities. Nevertheless, these policy initiatives are not sufficient because they 
neglect the most vulnerable subcontractors: the small traditional ones. Moreover, they fail to motivate a personal interest to participate in collective projects and to openly share their knowledge with other members.

Finally, we acknowledge that there are some limitations to our study. Firstly, the specificity of the population studied reduces the number of observations. But it also has the advantage that firms are relatively homogeneous. Innovation in pure subcontracting industries has rarely been a subject of interest even though it helps to better understand firms' competitiveness in low-tech industries. It would be interesting to confront these results with data from regions in other countries which still depend on these particular industries since this question has important implications for their future competitiveness. Secondly, we have to stress the limitation of an innovation survey to capture the impact of shared knowledge (that is intrinsically social and collective) on outsourcing performance (Blumenberg et al. 2009). Following the same methodology as the one chosen by Dyer and Nobeoka (2000), it would be interesting to highlight the quantitative results with qualitative data coming from interviews with contractors and subcontractors belonging to the same network. This would make it possible to distinguish the nature of the shared knowledge during the relation process (relation-specific knowledge versus redeployable knowledge) since it does not have the same impact on the suppliers' performance (Nobeoka et al., 2002). Thirdly, our study is a static cross-sectional analysis. Changes in the subcontracting relationships over time, underlying strategic and management processes as well as their impact on innovation cannot be identified. The analysis of project-related processes to manage supplier involvement (Van der Valk and Wynstra 2005) could be a complementary way of research. Lastly, we know that because of its cost-cutting nature, process innovation may have ambiguous effects on a firm's growth (Fagerberg 2005). Further research is needed to assess the impact of process and product innovations on subcontractors' competitive position. 
Acknowledgments: This paper has been funded by a General Council of Isère research grant. The author would also like to thank four anonymous referees for their constructive comments.

\section{References}

Amesse, F., Dragoste, L., Nollet, J. and Ponce, S. (2001) Issues on Partnering: Evidences from Subcontracting in Aeronautics, Technovation, 21, pp. 559-569.

Andersen, P. H. (1999) Organizing international technological collaboration in subcontractor relationships: an investigation of the knowledge-stickeness problem, Research Policy, 28, pp. 625-642

Athey, S., and Schumutzler, A. (1995) Product and process flexibility in an innovative environment, Rand Journal of Economics, 26(4), pp. 557-574

Baudry, B. (2004) Incitation et coordination dans la firme-réseau, Revue économique, 55(2), pp. 247-274.

Baudry, B. (2003) Economie de la firme (Paris, La découverte, Repères)

Baudry, B. (1995) L'économie des relations inter-firmes, (Paris, La découverte, Repères)

Blumenberg, S., Wagner H-T, Beimborn D. (2009) Knowledge transfer processes in IT outsourcing relationships and their impact on shared knowledge and outsourcing performance, International Journal of Information Management, 29 (5), pp. 342-52.

Bocquet, R and Brossard, O. (2007) Variety of ICT Adoption modes and second movers' behaviour. A Theoretical Analysis and Empirical Evidence, Structural Change and Economic Dynamics, 18( 4), pp. 409-437

Bocquet, R. and Brossard, O. (2008), Adoption des TIC, proximité et diffusion localisée des connaissances, Revue d'Economie Régionale et Urbaine, 3, pp. 411-446

Bruce, M. and Moger, S. (1999) Dangerous liaisons: an application of supply chain modelling for studying innovation within the UK clothing industry, Technology, Analysis and Strategic Management, 11(1), pp. 113-125

Cohen, W.M. and Levinthal, D.A. (1990) Absorptive capacity: A new perspective on learning and innovation, Administrative Science Quaterly, 35, pp. 128-152

Cohendet, P. and Llerena, P. (2005) A dual theory of the firm between transactions and competences: conceptual analysis and empirical considerations, Revue d'économie industrielle, 110, pp. 175-198

Damanpour, F. and Gopalakrishnan, S. (2001) The dynamics of the adoption of product and process innovations in organizations, Journal of Management Studies, 38(1), pp. 45-65

De Jong, J.P.J and Marsili, O. (2006) The fruit flies of innovations: A taxonomy of innovative small firms, Research Policy, 35, pp.213-229

Dyer, J.H. and Nobeoka K. (2000) Creating and managing a high performance knowledgesharing network: the Toyota case, Strategic Management Journal, 21, 345-367

Dyer, J.H. and Singh, H. (1998) The Relational View: Cooperative Strategy and Sources of Interorganizational Competitive Advantage, Academy of Management Review, 23(4), pp. 660-679.

Fagerberg, J. (2005) Innovation, a guide to the literature, in: Fagerberg J; Mowery D.C, Nelson R.R (eds), The Oxford Handbook of Innovation (Oxford University Press. New York), pp. 1-28

Fiol, C.M and Lyles, M.A (1985) Organizational learning. Academy of management review, 10(4), pp. 803-813

Freel, M.S (2000) Strategy and structure in innovative manufacturing in SMEs: The case of an English region, Small Business Economics, 15, pp. 27-45 
Freel, M.S and Harrison, R.T. (2006) Innovation and cooperation in the Small firm sector:

Evidence from 'Northern Britain', Regional Studies, 40(4), pp. 289-305

Hätönen, J.and Eriksson, T. (2009), 30+ years of research and practice of outsourcing -

Exploring the past and anticipating the future, Journal of International Management,

15 (2), pp.142-55

Hirsch-Kreinsen, H. (2008) "Low-Tech" Innovations, Industry and Innovation, 15(1), pp. $19-43$

Kraft, K. (1990) Are product- and process-innovations independent of each other? Applied Economics, 22, pp. 1029-1038

Iacovou Charalambos, L., Benbasat, I. and Dexter, A.S. (1995) Electronic data interchange and small organization: adoption and impact of technology, MIS Quaterly, 19(4), pp. 465485

Lamming, R. (1993) Beyond partnership: strategies for innovation and lean supply (NJ, Englewood cliffs, Prentice-Hall)

Lehtinen, U. (1999) Subcontractors in a partnership environment: a study on changing manufacturing strategy, International Journal of Production Economics, 60-61, pp. 165170

McIvor, R. (2009) How the transaction cost and resource-based theories of the firm inform outsourcing evaluation, Journal of Operations Management, 27 (1), pp. 45-63.

Mairesse, J., Mohnen, P. (2010) Using Innovations Surveys for Econometric Analysis, Working Paper 15857, National Bureau of Economic Research, April. Cambridge, MA.

Martinez-Ros, E. (2000) Explaining the decisions to carry out product and process innovations : the spanish case, The Journal of High Technology Management Research, 10(2) pp. 223-242

Nelson, R.R and Winter, S.G. (1982) An evolutionary Theory of Economic Change, (Cambridge, Massachusetts: Harvard University Press)

Nobeoka K., Dyer J.H. and Madhok A. (2002) The influence of customer scope on supplier learning and performance in the Japanese Automobile Industry, Journal of International Business Studies, 33(4) 717-736

Nonaka, I. and Takeuchi, H. (1995) The Knowledge-creating company: how Japanese companies create the dynamics of innovation (Oxford: Oxford University Press)

OECD (2005) Oslo manual. Proposed guidelines for collecting and interpreting technological innovation data (Paris: $3^{\text {rd }}$ edition)

Pardo, R., Rama, R. (2009), Technical capital and social capital in outsourcing networks: complements or subsitutes, in: Morroni M.(Ed), Corporate Governance, Organization and the firm: Cooperation and Outsourcing in the Global Economy, (Massachussets:Edward Elgar Publishing)

Pavitt, K. (1984) Sectoral patterns of technological change: towards a taxonomy and a theory, Research Policy, 13, pp. 343-373

Raymond, L. and Blili, S. (1997) Adopting EDI in a network enterprise: the case of subcontracting SMEs », European Journal of Purchasing \& Supply Management, 3(3), pp. 165-175.

Rouvinen, P. (2002) Characteristics of product and process innovators: some evidence from the Finnish innovation survey, Applied Economics Letters, 9, pp. 575-580

Sessi (2007) La sous-traitance industrielle en chiffres. Production industrielle (hors série), chiffres clés, (Paris: Ministère de l'économie, des finances et de l'industrie)

Smith, D.J. and Tranfield, D. (2005) Talented suppliers? Strategic change and innovation in the UK aerospace industry, $R \& D$ Management, 35, pp. 37-49

Sterlacchini, A. (1999) Do innovative activities matter to small firms in non-R\&D intensive 
industries? An application to export performance, Research Policy, 28, pp. 819-832

Takeishi, A. (2002) Knowledge partitioning in the interfirm division of labor: The case of automative Product development, Organization Science, 13 (3), pp. 321-338

Teece, D.J. (1996) Firm Organization, Industrial Structure and Technological Innovation, Journal of Economic behavior and Organization, 31, pp. 193-224.

Van der Valk, W. and Wynstra, F. (2005) Supplier involvement in new product development in the food industry, Industrial Marketing Management, 34, pp. 681-694

Van Echtelt, F.E.A., Wynstra, F., Van Weele, A.J. and Duysters, G. (2008) Managing Supplier involvement in New Product Developpement: a multiple-case study, The Journal of Product Innovation Management, 25, pp. 180-201

Vaona, A. and Pianta, M. (2008) Firm size and innovation in European manufacturing, Small Business Economics, 30, pp. 283-299

Weiss, P. (2003) Adoption of product and process innovations in differentiated markets: the impact of competition, Review of Industrial Organization, 23, pp. 301-314

Williamson, O.E (1999) Strategy research: governance and competence perspectives, Strategic Management Journal, 20(12), pp. 1087-1108

Williamson, O.E (1985) The Economic Institutions of Capitalism (New York: Free Press)

White, M., Braczyk, H., Ghobadian, A., and Niebuhr (1988) Small firms Innovation: why regions differ? (London: Policy Studies Institute)

Zhu, K. (2002) Information transparency in electronic marketplaces: why data transparency may hinder the adoption of B2B exchanges, Electronic markets, 12(2), pp. 92-99. 
Appendix: Data descriptives

Table A1. Firms' Industrial affiliation (SIC: 4 -digit)

Subcontracting industries

Parent population Sample

Metal cutting and forming

N (\%) n (\%)

Bar Turning (28.5)

$870(77,3) \quad 75(80,6)$

Mechanical (28.5)

$298(26,5) \quad 33(35,5)$

$355(31,5) \quad 24(25,8)$

Forge, stamping, cutting (28.4)

$217(19,3) \quad 18(19,4)$

Other subcontracting industries: Plastic and $256(22,7) \quad 18(19,4)$

rubber

Technical parts made of plastic (25.2), Moulds

and models (29.5), Springs and manufacturing

of other rubber items (25.1).

Total

$1126(100,0) \quad 93(100,0)$

Table A2. Firms' size

\begin{tabular}{lll}
\hline & Parent population & Sample \\
\cline { 2 - 3 } Size & $\mathbf{N ~ ( \% )}$ & $\mathbf{n}(\%)$ \\
Less than 10 employees & $498(44,2)$ & $48(51,6)$ \\
From 10 to 50 employees & $505(44,8)$ & $38(40,9)$ \\
More than 50 employees & $123(10,9)$ & $7(7,5)$ \\
Total & $1126(100,0)$ & $93(100,0)$ \\
\hline
\end{tabular}

Table A3. Descriptive statistics (\%)

\begin{tabular}{llll}
\hline Variables & Full sample & INOPROC & INOPROD \\
\cline { 2 - 3 } C1 & & \\
C2 & 44.1 & 31.7 & 34.1 \\
Organizational practices and tools & 60.2 & 59.6 & 48.1 \\
QUALI & 30.1 & 58.9 & \\
LPJAT & 19.4 & 53.6 & 42.8 \\
EDI & 18.3 & 38.9 & 53.6 \\
ERP & & 58.8 & 55.6 \\
Strategy variables & 38.7 & & 41.2 \\
DEVINOV & 72.0 & 44.4 & 47.2 \\
RATION & 28.0 & 53.7 & 35.8 \\
REDUCDEP & 84.9 & 42.3 & 38.5 \\
DIVER & 38.7 & 40.5 \\
Sources of knowledge supporting innovative activities & & \\
BERD & 22.6 & 76.2 & 54.0 \\
PREST & 23.7 & 63.6 & 45.5 \\
ACTIFS & 14.0 & 53.8 & 53.8 \\
RH & 60.2 & 58.2 & 50.9 \\
Control variables & & & \\
EFF1 & 51.6 & 43.8 & 33.3 \\
EFF2 & 48.4 & 53.3 & 48.9 \\
DEC & 35.4 & 51.6 & 39.4 \\
APE2 & 38.7 & 55.6 & 50 \\
MECA & 25.9 & 33.0 & 29.2 \\
\hline
\end{tabular}

